\title{
Congenital cystic adenomatoid malformation (CCAM) 出生前診断症例に対する周産期治療
}

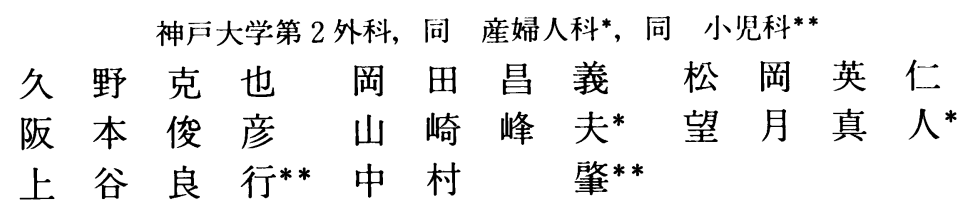

出生前診断された胎児 congenital cystic adenomatoid malformation（CCAM）の 2 例を超音波検査に より観察し, 出生後直ちに根治手術を行い順調に経過した。2例ともに, 本症の子後を悪化させる胎児水腫 が認められず経過観察となったが, 1 例では羊水過多のため早期破水をきたした。また両児ともに, 出生直 後より強い呼吸困難に陥り, high frequency oscillation (HFO) による呼吸管理により, 根治手術を施行 することが可能となった。本症では厳重な胎児期および周産期の管理が, 治療成績の向上に有用であった。

索引用語 congenital cystic adenomatoid malformation (CCAM), 出生前診断, high frequency oscillation (HFO)

\section{はじめに}

出生前診断を胎児期あるいは周産期にどのよう に治療に結び付けて行くかは, 小児外科の最も重 要な課題の 1 つである ${ }^{1)}$ 。近年, 子宮内胎児に直接 外科的処置を加える胎児治療報告例も増加してい $ろ^{2)}$ 。とりわけ, 出生直後に重症に陥る胸部外科疾 患が本治療の対象として注目されている。胎生期, 肺に発生する congenital cystic adenomatoid malformation (CCAM) も近年胎児診断される症 例が増加してきた。本症は, 出生直後より呼吸困 難を引き起こす症例が多く, 新生児緊急手術の対 象となる。胎児診断された本症 2 例の経験から， 本症の周産期管理と治療について述べる。

\section{症例}

神戸大学周産母子七ンターで, 最近の 10 年間に 経験した新生児外科疾患出生前診断症例は 37 例 で，疾患別には先天性小腸閉鎖症が 8 例で最も多 く, 呼吸障害の原因となる先天性横隔膜へルニア 5 例，CCAM は 2 例であった（表 1)。

症例 1 : 在胎 33 週 $1800 \mathrm{~g}$ で出生した男児であ
る。在胎 21 週に胎児超音波診断にて左胸腔内に囊 胞様腫瘤を指摘された。26 週には, 羊水過多を認 め経過観察を続けていたが, 33 週に入り羊水過多 のため破水し，母体搬送にて入院した。胎児超音 波診断所見では, 胎児胸腔の $50 \%$ 以上を占める腫 瘤を認め, 腫瘤内には直径 1-3 mm の囊胞が多数 見られた（図 1)。周産母子センター入院後, 新生 児科医，小児外科医が立会のもと経胵分娩となっ た。出生時 Apgar score 4 点の仮死で, 直ちに気 管内挿管し, $\mathrm{FiO}_{2} 1.0$ の用手換気を続けたが，血 液ガス所見は $\mathrm{PaO}_{2}=29 \mathrm{mmHg}, \mathrm{PaCO}_{2}=81$ $\mathrm{mmHg}$ と不良であったため, 呼吸管理を high frequency oscillation (HFO) に変更し, $\mathrm{PaO}_{2}=$ $86 \mathrm{mmHg}, \mathrm{PaCO}_{2}=26 \mathrm{mmHg}$ に著明に改善し た。出生直後の胸部 X 線撮影でも, 縦隔を右側に 圧排した左肺腫瘤をみとめ, 手術は左開胸により 大きな腫瘤を左肺下葉を含めて切除した。左肺上 葉は圧迫され形成不全であった。術後 HFO 5 日間, intermittent mandatory ventilation(IMV) を 10 日間の呼吸管理を行い weaning することが できた。切除標本は, 組織診断 CCAM で, 一部に 小震胞を含む充実性の Stocker 分類 II + III 型と 
Congenital cystic adenomatoid malformation (CCAM) 出生前診断症例に対する周産期治療

䛦断されだ)。患児の術後 1 力月の嘲シンチ検査 では，換気，血流シンチとも左肺の著明な低下を 認め, 1 年後にも十分な改善は認められていない。 症例 2 : 在胎 38 週, 生下時 $3030 \mathrm{~g}$ の男児。在胎 20 週に行われた超音波検查により, 左胸腔内に囊 胞状腫瘤を指摘された。36週の超音波検榃所見で は，此較的大きな囊胞を持つ腫瘤であったが，胸

表 1 出生前診断疾患

\begin{tabular}{|c|c|c|}
\hline 出生前診断疾患 & 症例数 & 手術症例 \\
\hline 小腸閉鎖症 & 8 & 8 \\
\hline 先天性横隔膜ヘルニア & 5 & 4 \\
\hline 臍帯ヘルニア & 4 & 2 \\
\hline 腹壁破裂 & 4 & 1 \\
\hline 胎便性腹膜桨 & 3 & 2 \\
\hline CCAM & 2 & $\underline{2}$ \\
\hline 直腸肛門奇形 & 2 & 2 \\
\hline リンパ罾腫 & 2 & 2 \\
\hline 腸間膜虽腫 & 1 & 1 \\
\hline 腎腫瘍 & 1 & 1 \\
\hline 卵巣襄腫 & 1 & 1 \\
\hline 食道閉鎖症 & 1 & 0 \\
\hline その他 & 3 & 1 \\
\hline 計 & 37 & 26 \\
\hline
\end{tabular}

(心矤患、中枢神経疾思、泌尿器聅患を除く)
腔の $50 \%$ には達していなかった（図2)。在胎 36 週まで外来で経過観察を続け, 母体搬送入院の後, 38 週帝王切開により出生した。Apgar score 6 点

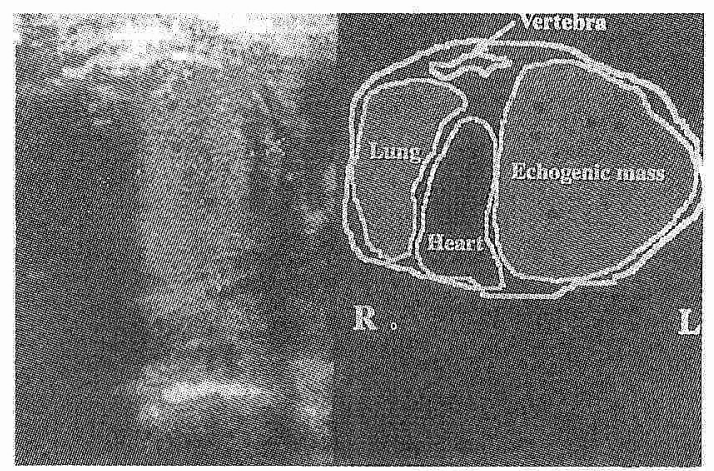

図１胎児超音波診断所見（症例 1，妊娠26週）

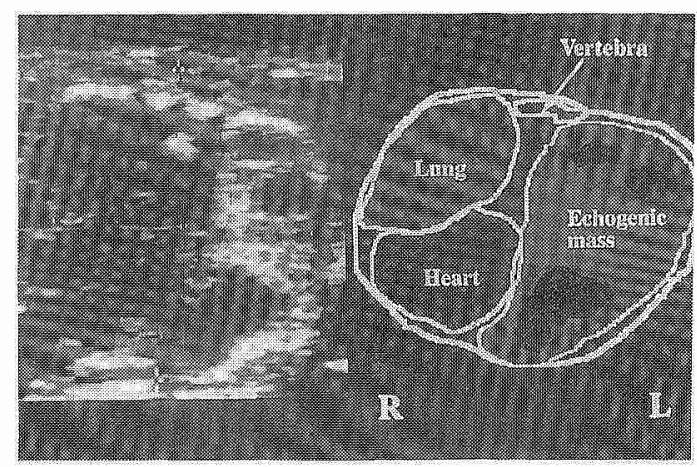

図 2 胎少超音波診断所見（症例 $2 ，$ 妊娠36週）

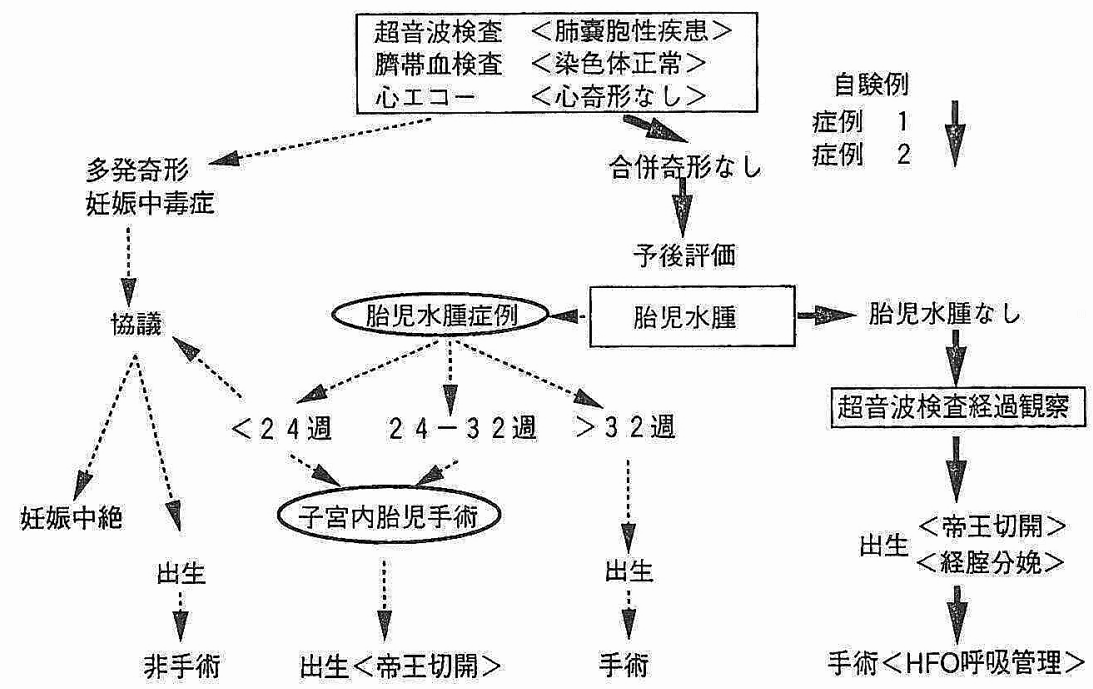

図3 胎皃 CCAM の管理 (M.R. Harrison Lり) 
のため直ちに呼吸管理を開始した。 $\mathrm{FiO}_{2} 0.8$ の controlled mechanical ventilation (CMV) で, $\mathrm{PaO}_{2}=60.3 \mathrm{mmHg}, \mathrm{PaCO}_{2}=63.2 \mathrm{mmHg}$ と不良 であったため, $\mathrm{HFO} に$ 変更し $\mathrm{PaO}_{2}=194$ $\mathrm{mmHg}, \mathrm{PaCO}_{2}=29 \mathrm{mmHg}$ に改善した。出生直後 の $\mathrm{X}$ 線写真では, 左肺野に大きな䡛胞を認めた。 手術は，大きく囊胞化した左上葉を切除し動脈管 を結紮した。組織診断は, 輁胞を形成する CCAM I 型であった。術後 10 日間の IMV 管理を要した が, その後順調に経過している。患側残存肺の 1 年 後の肺シンチ所見では，換気（左；24\%，右； 76 $\%$ ), 血流 (左；28\%，右； $72 \%$ ) の強い発育障害 を認めた。

\section{考察}

CCAM，横隔膜へルニアでは，胎児期の病態が 出生後の呼吸障害に強い影響を及ぼすため, 胎児 管理にとくに注目されている4)。とりわけ CCAM では，増大する腫瘤が縦隔を圧迫し，食道嚥下障 害による羊水過多や，心，大静脈圧迫による胎児 水腫を引き起こし，予後不良の原因となる。本症 は, 胎生期 5 週から 6 週に発生するとされており, 早期からの出生前診断, 経過観察が可能である ${ }^{5)}$ 。 III型が主であった症例 1 では小囊胞を含む充実性 腫瘤を，I 型の症例 2 では大きな䡛胞を胸腔内に 認め CCAM と診断された。胎児の経過観察は腫 瘤, 襄腫の増大, 胎児水腫や羊水過多の出現に特 に注意を払った。重症 CCAM 胎児に対しては, Harrison らによって胎児手術の有用性が報告さ れてきだ)。自験例 2 例は, 胎児水腫の徴候を認め ないため, プロトコールに従って経過観察を行っ た ${ }^{7}$ (図 3)。その結果, 症例 1 では急速に進行する 羊水過多に対応できず，早期破水を招いたが，か かる症例では縦隔偏位を観察しながら積極的に早 期に娩出させることも有用であろう。また，高度 の羊水過多には, カテーテル挿入による肺-羊水ド レナージの有用性も報告されている8)。シンチグ ラムで明らかにされた術後残存肺の機能障害を, 可及的に小さくするためには，これら胎児期の外 科処置も必要であろうと考えられた。分婏に際し ては，小児科医，小児外科医が立会い，HFO， extracorporeal membrane oxygenation
(ECMO)をスタンバイのうえ，直ちに呼吸管理が 行われた。本症では, 高い陽圧換気は襄腫の拡張 を増強し，かえって正常肺の換気を悪化させる原 因となるため，最高気道内圧を低く保つことがで き，ガス交換が良好な HFO が大変有効であっ た9)。さらに，術中にも HFO 換気を併用すること により，囊胞の拡張を抑えることができ，手術操 作上も有用であった。

本症は, 出生前診断により予後の向上が更に期 待できる疾患であろうと思われる。

\section{結論}

1. CCAM 出生前診断症例では, 妊娠経過中の 観察が重要で，羊水過多や胎児水腫などの合併症 は予後不良の原因となる。

2. CCAM 症例は, 出生後ただちに呼吸管理を 行い,さらに呼吸不全を来たす症例に対しては $\mathrm{HFO}$ が有用であった。

\section{文献}

1）久野克也, 岡田昌義, 中村和夫, 他：出生前診断 症例の手術適応．小児外科 $19 ： 211-218 ， 1987$

2) Harrison MR, Adzick NS, Longaker MT, et al: Successful repair in utero of a fetal diaphragmatic hernia after removal of herniated viscera from the left thorax. New Eng J Med 322 : 1582-1584, 1990

3) Stocker JT, Madewell JE, Drake RM : Congenital cystic adenomatoid malformation of the lung. Classification and morphologic spectrum. Hum Pathol 8: 155-171, 1977

4) Atkinson JB, Ford EG, Kitagawa $\mathrm{H}$ et al : Persistent pulmonary hypertension complicating cystic adenomatoid malformation in neonates. J Pediatr Surg 27 : 54-56, 1992

5) Halloran LG, Silverberg SG, Salzberg AM : Congenital cystic adenomatoid malformation of the lung. Arch Surg 104: 715-719, 1972

6) Harrison MR, Adzick NS, Jennings RW et al : Antenatal intervention for congenital cystic adenomatoid malformation. Lancet 336 : 965967, 1990

7) Adzick NS, Hanvison MR, Flake AW et al : 
Congenital cystic adenomatoid malformation (CCAM)出生前診断症例に对する周産期治療

Fetal surgery for cystic adenomatoid malformation of lung. J Pediatr Surg 28: 806-812, 1993

8) Clark SL, Vitale DJ, Minton SD et al: Successful fetal therapy for cystic adenomatoid malformation associated with second-trimester hydrops. Am J Obstet Gynecol 157 : 294-
297, 1987

9) Nakano S, Tashiro C, Nishimura $M$ et al: Perioperative use of high-frequency oscillation immediately after birth in two neonates with congenital cystic adenomatoid malformation. Anesthesiology 74 : 939-941, 1991 